\title{
Effect of Planting Methods and Copper Sulfate on Root Rot Disease and Enhancing Productivity of Irrigation Water on Sugar Beet Crop
}

\author{
M.A. Mahmoud ${ }^{1}$ and Gamal A. Farahat ${ }^{2}$ \\ ${ }^{I}$ Water Requirements and Field Irrigation Dept., Soils, Water and Environment Research Institute, \\ ARC, Giza, Egypt. \\ ${ }^{2}$ Maize and Sugar Crops Diseases Dept., Plant pathology Res. Institute. ARC, Agric. Res. Station, \\ Sakha, Egypt.
}

Received: 30 Oct. 2020 / Accepted 10 Dec. 2020 / Publication date: 20 Dec. 2020

\begin{abstract}
Two field trails were conducted in 2017/2018 and 2018/2019 winter seasons at Sakha Agricultural Research Station farm, Egypt to investigate the effect of different planting methods and application of copper sulfate to reduce root rot disease, enhance sugar beet yield and irrigation water productivity. A split-plot design was applied, planting methods were allocated in main plots, it included ridges $0.60 \mathrm{~m}$ apart $\left(\mathrm{M}_{1}\right)$, raised-beds $1.20 \mathrm{~m}$ apart $\left(\mathrm{M}_{2}\right)$ and wide raised-beds $1.80 \mathrm{~m}$ apart $\left(\mathrm{M}_{3}\right)$. Copper sulfate were assigned to sub plots at concentrations of $7.15 \mathrm{~kg} \mathrm{ha}^{-1}\left(\mathrm{Cu}_{1}\right), 10.71 \mathrm{~kg} \mathrm{ha}^{-1}\left(\mathrm{Cu}_{2}\right)$ and control $\left(\mathrm{Cu}_{0}\right)$. Results indicated that planting methods of $\mathrm{M}_{2}$ and $\mathrm{M}_{3}$ were reduced water consumptive use by $7.9 \%$ and $14.9 \%$ and saved 1217 and $1526 \mathrm{~m}^{3} \mathrm{ha}^{-1}$ of applied water, respectively compared to $\mathrm{M}_{1}$ in both growing seasons and had effective role in retarding root rot disease severity and index. Consequently, increased root yield, sugar yield and improved their quality. Adding of copper sulfate with all planting methods led to significant reduction root rot disease, improved yield quantity and quality especially with $\mathrm{M}_{2}$. Also copper sulfate in vitro reduced myceial growth, sporulation and/or sclerotia of mean root rot fungi, wherever Fusarium oxysporum was the most effective one followed by Rhizoctonia solani and Sclerotium rolfsii. Applying the interaction of $\mathrm{M}_{2} \times \mathrm{Cu}_{2}$ achieved the highest values of total soluble solids, sucrose, root yield, sugar yield, gross income, net return whereas, the lowest values of root rot disease severity and index, applied water and water consumptive use accordingly, productivity of irrigation water and water productivity for both root and sugar yield were improved.
\end{abstract}

Keywords: Sugar beet, root rot disease, copper sulfate, planting methods, water productivity

\section{Introduction}

Sugar beet (Beta vulgaris L.) is an essential sugar crop globally. In Egypt it is the second sugar crop after sugar cane, the harvested area was 207020 ha in 2018 with total production of 10377371 tons with an average productivity about 50.13 ton $\mathrm{ha}^{-1}$ (FAO, 2018). The expansion of sugar beet cropped area is an important target of the government to reduce the gap between the production and consumption of sugar, but the limitation of water resources in Egypt is a barrier. So on-farm irrigation management practices as raised beds planting method are being worked out to obtain maximum benefits from available resources. Raised beds planting method is an applicable on-farm practice to enhance water productivity, increase water application and distribution efficiencies, easily implemented by the farmers themselves and improve plant growth and yield optimization (Zhang et al. 2009; Mahmoud et al. 2016). Moreover, its increased fertilizer use efficiency and reduce weed intensification (Ahmad et al. 2010). It is a precise method for moisture conservation in situ in dry areas and an effective drainage tool in wet areas (Khambalkar et al. 2010). This technology has been tested for many field crops during the last few decades, the yield of faba bean, onion, chickpea and sugar beet was increased by increasing ridge width from $0.60 \mathrm{~m}$ to raised beds, while water consumptive use and applied water for sugar beet were reduced by $19-20 \%$ on raised beds, compared to $0.6 \mathrm{~m}$ ridge (Zohry and Ouda 2019). Raised beds panting method for sugar beet was reduced water consumptive use and saved significant amount of irrigation water, enhanced crop growth and yield, increased sugar content and increased water productivity and productivity of irrigation water compared to $0.6 \mathrm{~m}$ ridge, that is the common planting method on the study area (Ahmad et al. 2010; Marey 2015; Moursi and El-Mansoury 2015 and ElShamy et al. 2019). 
In Egypt, in addition to the scarcity of water resources, sugar beet is attacked by several root-rot pathogens mainly Rhizoctonia solani (Kuhn), the most damaging more than $24 \%$ of planted area and incidence seems to be increasing (Bartholomaus et al., 2017); Sclerotium rolfsii (Sacc) a serious disease in the irrigated region and disease incidence varied from traces to $50 \%$ (Fidah, 1995); F. oxysporum (Schlech), the most aggressive pathogens to cause root rot infection at both pre and post-emergence stage (Aly and Hussein, 2009). Several safe alternative ways in control of plant diseases were approaches $i e$. nutrition of micronutrients to plant crop results in decrease the incidence of many diseases and required for polyphenol formations and phenolic metabolism, hence for plant defense capability (Huber and Withelm, 1988 and Graham and Webb, 1991). Copper based antimicrobial with high toxicity to plant pathogens, low costs, low mammalian toxicity of the fixed compounds and their chemical stability (Lamichhane et al., 2018). In addition to, direct application of $\mathrm{Cu}$ on plants in the field, used to prevent infection by plant pathogens (Verma et al., 2011). Copper formulations $\mathrm{SO}_{4}$ used as biocide to control plant pathogenic fungi (Capinera and Dickens, 2016). Additionally, Farahat (2019) recorded that the fertilization by copper sulfate to maize plants led to retarding of soil born late wilt disease in the field, causing reduction of infection percentage and yield enhancement. Moreover, Farahat and Salama (2019) added that, $\mathrm{CuSO}_{4}$ was the most effective sulfate one in reducing of powdery mildew and retarding of Erysiphe betae fungus spores germination in vitro. For the best of our knowledge, the mutual effect of different planting methods and copper sulfate application on reduction of sugar beet root rot still needs further investigations. Therefore, the main objective of this study was to investigate the effect of different planting methods and application of copper sulfate as a safe promising solution of root rot disease under field conditions to increase sugar beet yield and sucrose, save irrigation water, enhance water productivity and achieve better disease management.

\section{Materials and Methods}

In winter seasons of 2017/2018 and 2018/2019, two field trails for sugar beet were established at Sakha Agricultural Research Station ( $31^{\circ} 07^{\prime} \mathrm{N}$ latitude, $30^{\circ} 57^{\prime}$ E longitude), North Nile Delta, Egypt. The Agro-meteorological data were taken from Sakha agro-meteorological station during both winter growing seasons as shown in Table (1).

Table 1: Monthly mean values of agro-meteorological data of Sakha station in 2017/2018 and 2018/2019 winter seasons.

\begin{tabular}{|c|c|c|c|c|c|c|c|c|c|c|}
\hline \multirow{2}{*}{ 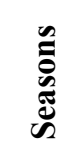 } & \multirow{2}{*}{ Months } & \multicolumn{3}{|c|}{$\begin{array}{c}\text { Air } \\
\text { temperature }\end{array}$} & \multicolumn{3}{|c|}{$\begin{array}{l}\text { Relative } \\
\text { humidity }\end{array}$} & \multirow{2}{*}{$\begin{array}{c}\text { Wind } \\
\text { Speed } \\
\text { Mean } \\
\left(\mathbf{k m ~ d}^{-1}\right) \\
\end{array}$} & \multirow{2}{*}{$\begin{array}{c}\text { Pan } \\
\text { evaporation } \\
\left(\mathbf{m m ~ d}^{-1}\right)\end{array}$} & \multirow{2}{*}{$\begin{array}{l}\text { Rain } \\
(\mathrm{mm})\end{array}$} \\
\hline & & $\begin{array}{l}\text { Max. } \\
\left({ }^{\circ} \mathbf{C}\right)\end{array}$ & $\begin{array}{l}\text { Min. } \\
\left({ }^{\circ} \mathrm{C}\right)\end{array}$ & $\begin{array}{c}\text { Mean } \\
\left({ }^{\circ} \mathrm{C}\right)\end{array}$ & $\begin{array}{l}\text { Max. } \\
(\%)\end{array}$ & $\begin{array}{c}\text { Min. } \\
(\%)\end{array}$ & $\begin{array}{c}\text { Mean } \\
(\%)\end{array}$ & & & \\
\hline \multirow{7}{*}{ 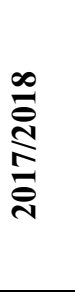 } & October & 28.70 & 24.00 & 26.35 & 81.10 & 54.70 & 67.90 & 73.20 & 3.26 & 0.00 \\
\hline & November & 23.70 & 19.9 & 21.80 & 84.70 & 58.60 & 71.65 & 53.50 & 2.06 & 9.30 \\
\hline & December & 21.50 & 18.40 & 19.95 & 88.20 & 64.80 & 76.50 & 42.90 & 1.48 & 5.60 \\
\hline & January & 18.90 & 13.60 & 16.25 & 89.40 & 64.40 & 76.90 & 44.90 & 2.63 & 36.40 \\
\hline & February & 21.60 & 14.60 & 18.10 & 87.60 & 63.40 & 75.50 & 34.70 & 2.78 & 16.60 \\
\hline & March & 25.40 & 16.60 & 21.00 & 82.30 & 48.30 & 65.30 & $46 . .40$ & 4.22 & 0.00 \\
\hline & April & 27.80 & 20.0 & 23.90 & 80.90 & 43.90 & 62.40 & 74.00 & 5.32 & 0.00 \\
\hline \multirow{7}{*}{ 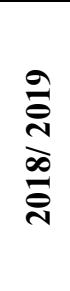 } & October & 29.50 & 20.60 & 25.05 & 82.50 & 49.60 & 66.05 & 57.90 & 3.24 & 3.50 \\
\hline & November & 25.00 & 17.40 & 21.20 & 86.60 & 54.60 & 70.60 & 24.20 & 1.60 & 11.90 \\
\hline & December & 19.50 & 13.90 & 16.70 & 88.70 & 62.40 & 75.55 & 24.50 & 0.84 & 21.70 \\
\hline & January & 18.90 & 12.30 & 15.60 & 82.30 & 53.30 & 67.80 & 33.10 & 1.14 & 14.90 \\
\hline & February & 19.70 & 14.30 & 17.00 & 86.90 & 58.2 & 72.55 & 28.60 & 1.78 & 15.30 \\
\hline & March & 21.70 & 17.60 & 19.65 & 87.80 & 56.60 & 72.20 & 45.70 & 2.86 & 17.3 \\
\hline & April & 25.10 & 21.30 & 23.20 & 80.80 & 48.60 & 64.70 & 44.80 & 3.70 & 3.90 \\
\hline
\end{tabular}

Soil properties of the experiments site were determined before cultivation process, Soil physical properties, ie. bulk density, particle-size distribution, field capacity and permanent wilting point were determined according to Klute (1986). Total porosity (P\%) was computed using values of soil bulk density according to Black (1965) Electrical conductivity in soil paste extract and soil pH were determined according to Page (1982) as shown in Table (2). 
Table 2: Some soil physical and chemical properties of the experimental site before cultivation (as mean values of the two studied seasons).

\begin{tabular}{ccccccccccc}
\hline $\begin{array}{c}\text { Soil } \\
\text { depth } \\
(\mathbf{c m})\end{array}$ & $\begin{array}{c}\text { Field } \\
\text { capacity } \\
(\mathbf{\%})\end{array}$ & $\begin{array}{c}\text { Wilting } \\
\text { point } \\
(\mathbf{\%})\end{array}$ & $\begin{array}{c}\text { Bulk } \\
\text { density } \\
\left(\mathbf{M g ~ m}^{-3}\right)\end{array}$ & $\begin{array}{c}\text { Total } \\
\text { porosity } \\
(\mathbf{\%})\end{array}$ & $\begin{array}{c}\text { Sand } \\
(\mathbf{\%})\end{array}$ & $\begin{array}{c}\text { Silt } \\
(\mathbf{\%})\end{array}$ & $\begin{array}{c}\text { Clay } \\
(\mathbf{\%})\end{array}$ & $\begin{array}{c}\text { Texture } \\
\text { class }\end{array}$ & $\begin{array}{c}\mathbf{E C}_{\mathbf{e}} \\
\left(\mathbf{d S S ~ m}^{-1}\right)\end{array}$ & $\mathbf{p H}$ \\
\hline $0-15$ & 44.03 & 23.65 & 1.17 & 55.85 & 18.67 & 27.93 & 53.40 & Clayey & 2.17 & 8.32 \\
$15-30$ & 41.25 & 21.84 & 1.23 & 53.58 & 19.25 & 27.92 & 52.83 & Clayey & 2.67 & 8.39 \\
$30-45$ & 36.23 & 19.43 & 1.35 & 49.06 & 20.14 & 27.54 & 52.32 & Clayey & 3.19 & 8.42 \\
$45-60$ & 37.12 & 20.11 & 1.41 & 46.79 & 21.03 & 28.30 & 50.67 & Clayey & 3.51 & 8.54 \\
\hline Mean & $\mathbf{3 9 . 6 6}$ & $\mathbf{2 1 . 2 6}$ & $\mathbf{1 . 2 9}$ & $\mathbf{5 1 . 3 2}$ & $\mathbf{1 9 . 7 7}$ & $\mathbf{2 7 . 9 2}$ & $\mathbf{5 2 . 3 1}$ & & $\mathbf{2 . 8 9}$ & \\
\hline
\end{tabular}

\section{Experimental design and treatments:}

The experiment was laid out in split-plot design with three replicates. Planting methods were in the main plots, which included: ridges (one row on $0.6 \mathrm{~m}$ apart, $\mathrm{M}_{1}$ ), as a farmer practices; raised beds (double rows on $1.2 \mathrm{~m}$ apart, $\mathrm{M}_{2}$ ) and wide raised beds (three rows on $1.8 \mathrm{~m}$ apart, $\mathrm{M}_{3}$ ). Copper sulfate $\left(\mathrm{CuSO}_{4} .5 \mathrm{H}_{2} \mathrm{O}, \mathrm{MW} .159 .609\right.$, El Nasr Pharm. Chem. Co. Production, Egypt) treatments were located in the sub plots at concentration of $7.15 \mathrm{~kg} \mathrm{ha}^{-1}\left(\mathrm{Cu}_{1}\right)$ and $10.71 \mathrm{~kg} \mathrm{ha}^{-1}\left(\mathrm{Cu}_{2}\right)$ added separately beside sugar beet plants, $c v$. Maximose., in addition to control treatment $\left(\mathrm{Cu}_{0}\right)$ without $\mathrm{CuSO}_{4}$, Application of copper sulfate was done after 130 days from sowing date (pre last irrigation) by banding at about 2-5 $\mathrm{cm}$ away from plants a drill manually by hand. The plots were isolated by ditches of $2.5 \mathrm{~m}$ in width to avoid lateral movement of water. All agricultural practices were done at optimal recommendation.

\section{Applied water:}

The applied irrigation water to each experimental plot was measured using two spiles PVC tubes of $7.5 \mathrm{~cm}$ inner diameter and $80 \mathrm{~cm}$ length to deliver water from field ditches into each plot. The effective head of water above the cross section center of irrigation spile was measured numerous times regularly during irrigation and the average value was $10 \mathrm{~cm}$. The water in the canal of the field was controlled to maintain a constant head by means of fixed sliding type gates. The irrigation water was added until it irrigates the whole plot, and the time of the irrigation was monitored using a stop watch. The amount of water delivered through the spile tube was calculated according to Majumdar (2002) by the following equation.

$$
\mathrm{q}=\mathrm{CA} \sqrt{ } 2 \mathrm{gh}
$$

Where: $\mathrm{q}$ is the discharge of irrigation water $\left(\mathrm{cm}^{3} \mathrm{sec}^{-1}\right), \mathrm{C}$ is a discharge coefficient equal 0.62 (determined by experiment), $\mathrm{A}$ is the inner cross section area of the irrigation spile $\left(\mathrm{cm}^{2}\right), \mathrm{g}$ is a gravity acceleration $\left(\mathrm{cm} \mathrm{sec}^{-2}\right)$, and $\mathrm{h}$ is the average effective head $(\mathrm{cm})$.

The volume of water delivered for each plot $\left(6 \mathrm{~m} \times 7 \mathrm{~m}=42 \mathrm{~m}^{2}\right)$ was calculated by substituting $Q$ in the following equation.

$$
\mathrm{Q}=\mathrm{q} \times \mathrm{t} \times \mathrm{n}
$$

Where: $\mathrm{Q}$ is the volume of water $\mathrm{m}^{3}$ plot $^{-1}, \mathrm{q}$ is the discharge $\left(\mathrm{m}^{3} \mathrm{~min}^{-1}\right), \mathrm{t}$ is total irrigation time (min) and $\mathrm{n}$ is number of spiles tube per each plot.

The seasonal applied water during the whole growing season, which includes effective rainfall was calculated according to Early (1975), following equation.

AW $\left(\mathrm{m}^{3} \mathrm{ha}^{-1}\right)=\mathrm{IW}+\mathrm{R}$

Where: AW is the amount of seasonal applied water $\left(\mathrm{m}^{3} \mathrm{ha}^{-1}\right)$, IW is the amount of water delivered to the field by irrigation $\left(\mathrm{m}^{3} \mathrm{ha}^{-1}\right)$ and $\mathrm{R}$ is the effective rainfall $\left(\mathrm{m}^{3} \mathrm{ha}^{-1}\right)^{*}\left[{ }^{*}\right.$ Effective rainfall $=$ incident rainfall $\times 0.70($ Novica, 1979)] .

\section{Water consumptive use $(\mathrm{CU})$ :}

Water consumptive use was calculated as a soil moisture depletion (SMD) in the effective root zone $(60 \mathrm{~cm})$ using the following equation of Israelsen and Hansen (1962).

$$
\mathrm{CU}=\sum_{i=1}^{n=4} \operatorname{Di} \mathrm{x} \operatorname{Bd} \mathrm{x}\left(\theta_{2}-\theta_{1}\right) / 100
$$

Where: $\mathrm{CU}=$ Water consumptive use $(\mathrm{cm})$. 
$\mathrm{Di}=$ Soil depth layer $(15 \mathrm{~cm})$.

$\mathrm{Bd}=$ Soil bulk density, $\left(\mathrm{Mg} \mathrm{m}^{-3}\right)$ for this depth

$\theta_{1}=$ Gravimetric soil moisture percentage immediately before the next irrigation.

$\theta_{2}=$ Gravimetric soil moisture percentage $48 \mathrm{~h}$ after irrigation.

$\mathrm{n}=$ Number of soil layers.

\section{Assessments of root rot disease, yield and its components:}

Plants were uprooted and roots were checked for root-rotting. Percentage of infected roots and disease severity were recorded as rating $0-4$ grades as follows : $0=$ no disease, $1=$ less than $25 \%$ of vascular element necrotic or localized lesions on root, $2=26-50 \%$ vascular necrosis or less than $10 \%$ of taproot rotted,3= over 50\% necrosis vascular elements and 10-25of taproot rotted, and $4=$ more than $25 \%$ taproot rotted and disease index (DI) were calculated from root disease rating as Harveson and Rush(1994)using equation:

$\mathrm{DI}=(D R 1 \times 1+D R 2 \times 2+D R 3 \times 3+D R 4 \times 4) /(E D R 0-4)$, where $D R 0=$ number of roots rated $0, D R 1=$ number of roots rated 1 , et. after harvesting directly at 180 days from sowing date. The percentage of sucrose and total soluble solids (TSS) were estimated of the fresh harvested roots using Sacarometer and Refrectometer according to AOAC (1990) and McGinnis (1982), respectively.

Root yield was estimated from the central three rows of each plot (area of $10 \mathrm{~m}^{2}$ ) and estimated to ton $\mathrm{ha}^{-1}$. The sugar yield (ton ha $\mathrm{h}^{-1}$ ) was estimated as the percentage of sucrose multiplied by root yield.

\section{Productivity of irrigation water (PIW) and water productivity (WP):}

Productivity of irrigation water (PIW) is generally defined as the ratio between crop yield and the total amount of applied water, that including effective rainfall. It was calculated according to Ali et al., (2007) by the following equation.

$$
\mathrm{PIW}=\frac{\mathrm{Y}}{\mathrm{AW}}
$$

Where: PIW $=$ Productivity of irrigation water $\left(\mathrm{kg} \mathrm{m}^{-3}\right), \mathrm{Y}=$ Yield $\left(\mathrm{kg} \mathrm{ha}^{-1}\right)$ and AW $=$ Applied water $\left(\mathrm{m}^{3} \mathrm{ha}^{-1}\right)$.

The Productivity of irrigation water in $\mathrm{kg}$ root yield per $\mathrm{m}^{3}$ applied water $\left(\mathrm{PIW}_{\mathrm{R}}\right)$ and Productivity of irrigation water in $\mathrm{kg}$ sugar yield per $\mathrm{m}^{3}$ applied water $\left(\mathrm{PIW}_{\mathrm{S}}\right)$ were calculated.

Water productivity (WP), is generally defined as crop yield $(\mathrm{kg})$ per $\mathrm{m}^{3}$ of crop water consumptive use. It was calculated according to Ali et al. (2007) by the following equation.

$$
\mathrm{WP}=\frac{\mathrm{Y}}{\mathrm{CU}}
$$

Where: $\mathrm{WP}=$ Water productivity $\left(\mathrm{kg} \mathrm{m}^{-3}\right), \mathrm{Y}=\mathrm{Yield}\left(\mathrm{kg} \mathrm{ha}^{-1}\right)$ and $\mathrm{CU}=\mathrm{Crop}$ water consumptive use $\left(\mathrm{m}^{3} \mathrm{ha}^{-1}\right)$.

Water productivity in $\mathrm{kg}$ root yield per $\mathrm{m}^{3}$ water consumptive use $\left(\mathrm{WP}_{\mathrm{R}}\right)$ and water productivity in $\mathrm{kg}$ sugar yield per $\mathrm{m}^{3}$ water consumptive use $\left(\mathrm{WP}_{\mathrm{S}}\right)$ were calculated.

\section{Effect of Copper sulfate on root rot fungi in vitro:}

Supplemental experiment was conducted in vitro using copper sulfate at $2.5,5.0$, and $7.5 \mathrm{~g} / \mathrm{L}$ of PDA medium to study their effect against mycelial growth in vitro of three major causal pathogens of root rot disease in sugar beet plants, ie. F.oxysporum, R.solani and Sc .rolfsii fungi which isolated from kafr elshiekh location. This salt was adjusted to obtain the desired concentrations on PDA medium. A mycelial discs $(9 \mathrm{~mm})$ diameter were taken from marginal growth of 4 days old cultures and placed on the center of Petri plates. Control treatment was tested fungi alone separately only on PDA. All treatments were incubated at $25^{\circ} \mathrm{C}$ and the growth was recorded $/ \mathrm{cm}$ after 7 days, four replicates were used for each treatment. Percentage of growth inhibition (PI) was calculated as: PI $=$ Treatment - control /control $\times 100$, number of sclerotia for R.solani and Sc .rolfsii were counted and sporulation of F.oxysporum / plate were estimated microscopically at $40 \mathrm{x}$ magnification by helping of hymacytometer plate as Mandeel and Baker (1991).

\section{Economic feasibility:}

Economic analysis was calculated according to Heady and Dillon (1961) according to the dominant market price during 2017/2018 and 2018/2019 growing seasons as following: 
Gross income $\left(\right.$ L.E. ha $\left.{ }^{-1}\right)=$ total yield (root yield ton ha $\left.{ }^{-1}\right) \times$ price of ton (L.E.) + shoot price $\left(\right.$ L.E. ha $\left.{ }^{-1}\right)$.

Net return $\left(\right.$ L.E. ha $\left.^{-1}\right)=$ gross income - total cost of production.

Profit margin $=$ net return/ Gross income

Return of Pound $=$ net return/ total cost of production

Benefit $/$ cost ratio $=$ gross income $/$ total cost

\section{Statistical analysis}

The collected data were subjected to proper statistical analysis of variance according to Snedecor and Cochran (1971). The collected data were directly analysed by MSTATC program using Duncan's Multiple Range Test (Duncan, 1955).

\section{Results and Discussion}

\section{Water consumptive use and applied water:}

Data in Table (3) showed the monthly and cumulative water consumptive use and applied water as mean of the two growing seasons. Planting method of $\mathrm{M}_{2}$ and $\mathrm{M}_{3}$ were reduced water consumptive use by $7.9 \%$ and $14.9 \%$ respectively compared to $M_{1}$. The water saving were 1217 and $1526 \mathrm{~m}^{3} \mathrm{ha}^{-1}$, these amount equal $19.2 \%$ and $24.1 \%$ for $\mathrm{M}_{2}$ and $\mathrm{M}_{3}$, respectively, compared to $\mathrm{M}_{1}$ as an average of the two growing seasons. These results were in harmony with previous reported by Zohry and Ouda (2019), they reported that water consumptive use and applied water of sugar beet were reduced by 19$20 \%$ on raised-beds, compared to $0.6 \mathrm{~m}$ ridge width. Moursi and El-Mansoury (2015) found the saved amount of applied water using raised-beds cultivation method was $591.5 \mathrm{~m}^{3} \mathrm{ha}^{-1}(8.9 \%)$ compared to traditional ridges planting method. These results also close to which obtained by El-Shamy et al. (2019). This could be attributed to the reduction of number of water ways and irrigation inlets, which reducing irrigated area, deep percolation, seepage and evaporation under raised-beds conditions, and hence, decreasing amount of applied water in contrast under normal ridges planting method (Marey, 2015; Moursi and El-Mansoury, 2015).

Table 3: Monthly, seasonal sugar beet consumptive use $(\mathrm{mm})$ and applied water $\left(\mathrm{m}^{3} \mathrm{ha}^{-1}\right)$ as an average of 2017/2018 and 2018/2019 growing seasons.

\begin{tabular}{|c|c|c|c|c|c|c|c|c|c|c|}
\hline \multicolumn{2}{|c|}{ Treatments } & \multicolumn{7}{|c|}{ Monthly water consumptive use (mm) } & \multirow{2}{*}{$\begin{array}{c}\text { Seasonal } \\
\text { rates } \\
(\mathrm{mm})\end{array}$} & \multirow{2}{*}{$\begin{array}{c}\text { Applied } \\
\text { water } \\
\left(\mathrm{m}^{3} \mathbf{h a}^{-1}\right)\end{array}$} \\
\hline & & Oct. & Nov. & Dec. & Jan. & Feb. & March & April & & \\
\hline \multirow{3}{*}{ M1 } & Cu 1 & 18.2 & 31.6 & 51.6 & 61.5 & 72.1 & 109.6 & 96.1 & 440.7 & 6357 \\
\hline & Cu 2 & 18.2 & 31.6 & 53.5 & 63.1 & 73.7 & 112.4 & 99.3 & 451.8 & 6674 \\
\hline & Cu 0 & 18.2 & 31.6 & 50.1 & 60.7 & 70.5 & 106.5 & 94.1 & 431.7 & 5995 \\
\hline \multicolumn{2}{|c|}{ Mean } & 18.2 & 31.6 & 51.7 & 61.8 & 72.1 & 109.5 & 96.5 & 441.4 & 6342 \\
\hline \multirow{3}{*}{ M2 } & Cu1 & 18.2 & 31.6 & 49.4 & 58.1 & 64.8 & 96.5 & 88.1 & 406.7 & 5207 \\
\hline & $\mathrm{Cu} 2$ & 18.2 & 31.6 & 50.2 & 60.9 & 65.4 & 98.1 & 89.0 & 413.4 & 5140 \\
\hline & Cu0 & 18.2 & 31.6 & 47.6 & 57.4 & 63.3 & 93.7 & 87.5 & 399.3 & 5029 \\
\hline \multicolumn{2}{|c|}{ Mean } & 18.2 & 31.6 & 49.1 & 58.8 & 64.5 & 96.1 & 88.2 & 406.5 & 5125 \\
\hline \multirow{3}{*}{ M3 } & Cu 1 & 18.2 & 31.6 & 47.5 & 55.4 & 61.3 & 89.1 & 76.1 & 379.2 & 4812 \\
\hline & Cu 2 & 18.2 & 31.6 & 48.4 & 56.7 & 60.5 & 88.1 & 77.8 & 381.3 & 5010 \\
\hline & Cu 0 & 18.2 & 31.6 & 47.1 & 54.4 & 58.1 & 82.9 & 74.4 & 366.7 & 4626 \\
\hline \multicolumn{2}{|c|}{ Mean } & 18.2 & 31.6 & 47.7 & 55.5 & 60.0 & 86.7 & 76.1 & 375.7 & 4816 \\
\hline
\end{tabular}

They also found water consumptive use under traditional ridges planting method was increased compared to raised-beds, this may be due to the strong growth of plants with thick vegetative cover, so the exposed plant area to the sunlight increases, thus water losses by transpiration increases. Otherwise, raised-beds size is comparatively less erected and bigger in size than ridges which can hold more moisture contents for longer time (Scott and Jaggard, 1993 and Ahmad et al. 2010). The lowest water consumptive use and applied water were found after $\mathrm{Cu}_{0}$ compared to $\mathrm{Cu}_{1}$ and $\mathrm{Cu}_{2}$ treatments. Water consumptive use was increased by $2.4 \%$ and $4.1 \%$, however applied water was increased by $4.6 \%$ and $7.5 \%$ for $\mathrm{Cu}_{1}$ and $\mathrm{Cu}_{2}$ respectively compared to $\mathrm{Cu}_{0}$ as mean of both seasons. There are noticeable differences were found of the interaction between planting methods and copper sulfate concentrations, the highest values of water consumptive use and applied water were recorded after $\mathrm{M}_{1} \times \mathrm{Cu}_{2}$ interaction, while the lowest values were showed after $\mathrm{M}_{3} \times \mathrm{Cu}_{0}$ interaction. The interaction of $\mathrm{M}_{2} \times \mathrm{Cu}_{2}$ was 
reduced water consumptive use and saved applied water by $4.2 \%$ and $14.3 \%$ respectively compared to $\mathrm{M}_{1} \mathrm{x} \mathrm{C \textrm {Cu } _ { 0 }}$ as a mean for the two seasons as shown in Table (3).

\section{Effect of planting methods and copper sulfate of root rot disease:}

The relationship between the planting methods and root rot disease of sugar beet plants presented in Table (4), that are obvious and indicated that, $\mathrm{M}_{2}$ (raised-beds $1.20 \mathrm{~m}$ ) and $\mathrm{M}_{3}$ (wide raised-beds 1.80 $\mathrm{m}$ ) were the most effective planting methods in retarding of root rot disease than $\mathrm{M}_{1}$ (ridges $0.60 \mathrm{~m}$, traditional planting method) in the field during both tested seasons of 2017/2018 and 2018/2019, these treatments led to reduce most of disease parameters. Planting method of $\mathrm{M}_{2}$ was the best one, it recorded the least values of Disease Severity \% (DS) and Disease index \% (DI) compare to $\mathrm{M}_{1}$. At all, disease parameters were higher in the first season than the second season. The infection percentage (IP) was affected only in the first season, but their values in the two seasons was ranged from 1.14-12.93\%, DS was ranged from 1.01-2.02, DI was ranged from 0.41-2.03\%. About the effect of copper sulfate on sugar beet root rot disease, $\mathrm{Cu}_{1}$ and $\mathrm{Cu}_{2}$ led to decrease of DS and DI in the two tested seasons. The values of DS and DI were decreased significantly under $\mathrm{Cu}_{1}$ and $\mathrm{Cu}_{2}$ compared to $\mathrm{Cu}_{0}$, especially in the second season. The range values of IP, DS and DI were 1.82-8.10\%, 1.01-1.42 and 0.46-1.27, respectively for $\mathrm{Cu}_{1}$ and $\mathrm{Cu}_{2}$ in the two growing seasons compare to $3.65-13.50 \%, 1.41-2.28$ and 1.13$2.40 \%$ respectively for $\mathrm{Cu}_{0}$ in the two growing seasons.

The interaction between planting methods and copper sulfate are shown in the same table. At all, traditional planting method without copper sulfate $\left(\mathrm{M}_{1} \times \mathrm{Cu}_{0}\right)$ treatment was recorded the highest values of DS and DI compared to all other studied treatments in the two seasons. But the results showed that, application of copper sulfate to traditional planting method was contributed to decrease of DS and DI, wherever $\mathrm{Cu}_{2}$ was more effective than $\mathrm{Cu}_{1}$. While raised-beds as $1.20 \mathrm{~m}$ without copper sulfate $\left(\mathrm{M}_{2}\right.$ $\mathrm{x} \mathrm{Cu}_{0}$ ) interaction was led to reduce the values of DS and DI compared to $\mathrm{M}_{1} \times \mathrm{Cu}_{0}$ interaction, especially on the second season. Adding of copper sulfate to planting method of $\mathrm{M}_{2}$ was led to decrease of DS and DI in the two studied seasons and showed the best one in retarding of the disease especially with $\mathrm{Cu}_{2}$.

The interaction of wide raised-beds as $1.80 \mathrm{~m}$ without copper sulfate $\left(\mathrm{M}_{3} \times \mathrm{Cu}_{0}\right)$ was decreased the DI in the two tested seasons and DS in the first season only compared to $\mathrm{M}_{1} \times \mathrm{Cu}_{0}$ interaction. Application of copper sulfate to $\mathrm{M}_{3}$ planting method was significantly decreased root rot disease, ie. DS and DI. The interaction of $\mathrm{M}_{2} \times \mathrm{Cu}_{0}$ followed by $\mathrm{M}_{3} \times \mathrm{Cu}_{0}$ were recorded the lowest sugar beet root rot disease as DS and DI compared to $\mathrm{M}_{1} \times \mathrm{Cu}_{0}$ interaction. Adding of high concentration of copper sulfate, ie. $\mathrm{Cu}_{2}$ followed by $\mathrm{Cu}_{1}$ with the three planting methods were significantly increased of disease retarding. These results may be due to the importance of soil moisture content in abundance of root rot disease, so both of planting methods $\mathrm{M}_{2}$ and $\mathrm{M}_{3}$ were recorded the lowest values of root rot disease compared to $\mathrm{M}_{1}$, which received higher amount of irrigation water as shown in Table (3). The results of which suggested the effective reduction of root rot can be achieved in the field supporting by Harveson and Rush (2002) and Fidah(1995), they found that moist soil conditions are favorable to sugar beet soil pathogens and higher soil moisture resulted in higher disease incidence. Field diseases control by $\mathrm{Cu}$ application and yield enhancement were achieved as found by Farahat (2019) with late wilt disease and led to prevent infection by plant pathogens(Verma et al. , 2011) as a biocide of $\mathrm{SO}_{4}$ formulation to fungi (Capinera and Dickens ,2016). Consequently, many diseases were retarded by copper sulfate application, ie. powdery mildew of sugar beet in field conditions ( Eliwa et al. ,2018 ; Farahat and Salama 2019) and on cucumber plants with elevated of peroxidase and glucanase activity. Moreover, fertilizer with $\mathrm{Cu}$ could reduce fungal epidemics by diminishing (Precigout et al. , 2017). As $\mathrm{Cu}$ mechanisms effects, acts as biocide to plant pathogens due to its interaction with nuclic acid, disruption of enzymes active sites, interference with energy transport system, and disruption of cell membrane (Fleming and Trevors, 1989) and antimicrobial with high toxicity and stability( Lamichhane et al., 2018). Our finding are consistently with the hypothesis that, the beneficial effect of nutrients are related to reduce or prevent infection by inhibitory compounds as phenols, phytoalexins and auxins around the infection sites (Long et al., 2003) and hence crucial plant defense (Graham and Webb,1991). From above results and data demonstrated in Table (2) sugar beet root rot disease pathogens found and habited in depth of soil $0-15 \mathrm{~cm}$ which physical and chemical soil properties are suitable and set as more active, ie. field capacity (44.03\%), wilting point (23.65\%), bulk density 
$\left(1.17 \mathrm{Mgm}^{-3}\right)$, total porosity (55.85\%), sand (18.67\%), silt (27.93\%), clay $(53.40 \%)$, EC $\left(2.17 \mathrm{dSm}^{-1}\right)$, $\mathrm{pH}(8.32)$ and texture class clay than others one.

Table 4: Effect of planting methods and copper sulfate on root rot disease of sugar beet in 2017/2018 and 2018/2019 seasons.

\begin{tabular}{|c|c|c|c|c|c|c|c|c|}
\hline \multirow{2}{*}{\multicolumn{2}{|c|}{ Treatments }} & \multirow[b]{2}{*}{ Seasons } & \multicolumn{2}{|c|}{ Infection percentage } & \multicolumn{2}{|c|}{ Disease Severity (\%) } & \multicolumn{2}{|c|}{ Disease index (\%) } \\
\hline & & & $1^{\text {st }}$ season & $2^{\text {nd }}$ season & $1^{\text {st }}$ season & $2^{\text {nd }}$ season & $1^{\text {st }}$ season & $2^{\text {nd }}$ season \\
\hline \multirow{3}{*}{\multicolumn{2}{|c|}{ 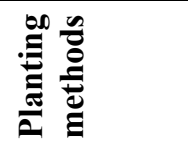 }} & M1 & $5.00 \mathrm{~b}$ & $5.07 \mathrm{a}$ & $2.02 \mathrm{a}$ & $1.57 \mathrm{a}$ & $2.03 a$ & $1.56 \mathrm{a}$ \\
\hline & & M2 & $12.93 \mathrm{a}$ & $1.58 \mathrm{~b}$ & $1.46 \mathrm{~b}$ & $1.01 \mathrm{~b}$ & $1.20 \mathrm{~b}$ & $0.41 \mathrm{~b}$ \\
\hline & & M3 & $11.02 \mathrm{a}$ & $1.14 \mathrm{~b}$ & $1.51 \mathrm{~b}$ & $1.01 \mathrm{~b}$ & $1.39 \mathrm{c}$ & $0.42 b$ \\
\hline \multirow{3}{*}{\multicolumn{2}{|c|}{ 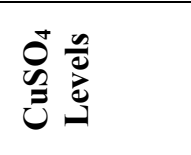 }} & Cu1 & $7.35 \mathrm{~b}$ & $2.32 \mathrm{~b}$ & $1.42 \mathrm{~b}$ & $1.17 \mathrm{~b}$ & $1.27 \mathrm{~b}$ & $0.81 \mathrm{~b}$ \\
\hline & & $\mathrm{Cu} 2$ & $8.10 \mathrm{~b}$ & $1.82 \mathrm{~b}$ & $1.29 \mathrm{~b}$ & $1.01 \mathrm{c}$ & $0.94 \mathrm{c}$ & $0.46 \mathrm{c}$ \\
\hline & & $\mathrm{CuO}$ & $13.50 \mathrm{a}$ & $3.65 \mathrm{a}$ & $2.28 \mathrm{a}$ & $1.41 \mathrm{a}$ & $2.40 \mathrm{a}$ & $1.13 \mathrm{a}$ \\
\hline \multirow{9}{*}{ 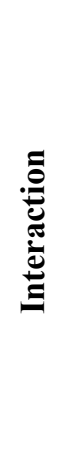 } & \multirow{3}{*}{ M1 } & Cu1 & $2.75 \mathrm{c}$ & $5.22 \mathrm{~b}$ & $1.73 \mathrm{~b}$ & $1.51 \mathrm{~b}$ & $1.82 \mathrm{c}$ & $1.91 \mathrm{a}$ \\
\hline & & $\mathrm{Cu} 2$ & $2.07 \mathrm{c}$ & $3.33 \mathrm{c}$ & $1.43 \mathrm{c}$ & $1.00 \mathrm{c}$ & $0.95 \mathrm{e}$ & $0.86 \mathrm{~b}$ \\
\hline & & Cu0 & $10.18 \mathrm{~b}$ & $6.67 \mathrm{a}$ & $2.91 \mathrm{a}$ & $2.26 \mathrm{a}$ & $3.31 \mathrm{a}$ & $1.91 \mathrm{a}$ \\
\hline & \multirow{3}{*}{ M2 } & Cu1 & $10.01 \mathrm{~b}$ & $0.89 \mathrm{~d}$ & $1.21 \mathrm{c}$ & $1.00 \mathrm{c}$ & $0.95 \mathrm{e}$ & $0.25 \mathrm{f}$ \\
\hline & & $\mathrm{Cu} 2$ & $14.01 \mathrm{a}$ & $1.03 \mathrm{~d}$ & $1.23 \mathrm{c}$ & $1.00 \mathrm{c}$ & $0.79 \mathrm{f}$ & $0.25 f$ \\
\hline & & Cu0 & $14.14 \mathrm{a}$ & $2.82 \mathrm{c}$ & $1.93 b$ & $1.01 \mathrm{c}$ & $1.85 \mathrm{c}$ & $0.73 \mathrm{~d}$ \\
\hline & \multirow{3}{*}{ M3 } & Cu1 & $9.30 \mathrm{~b}$ & $0.27 \mathrm{~d}$ & $1.42 b$ & $1.01 \mathrm{c}$ & $1.05 \mathrm{~d}$ & $0.25 f$ \\
\hline & & $\mathrm{Cu} 2$ & $8.23 \mathrm{~b}$ & $1.08 \mathrm{~d}$ & $1.29 b$ & $1.01 \mathrm{c}$ & $1.0 .9 \mathrm{~d}$ & $0.27 \mathrm{e}$ \\
\hline & & Cu0 & $15.53 \mathrm{a}$ & $1.46 \mathrm{~d}$ & $2.02 \mathrm{a}$ & $1.02 \mathrm{c}$ & $2.03 b$ & 0.75 \\
\hline
\end{tabular}

Means followed by the same partition lower cases letter within a character are not significantly different, $\mathrm{P}=0.05 \%$.

\section{Sugar beet yield and its quality:}

The values of TSS, sucrose percentage, root yield and sugar yield are presented in Table (5). There are significant differences in TSS, sucrose percentage, root yield and sugar yield between different planting methods, copper sulfate concentrations and the interaction between planting methods and copper sulfate concentrations. The highest values of TSS, sucrose percentage, root yield and sugar yield were recorded with planting method $\mathrm{M}_{2}$ compared to $\mathrm{M}_{1}$ and $\mathrm{M}_{3}$, since it was increased by $6.3 \%$, $7.3 \%, 12.5 \%$ and $20.4 \%$, respectively for $\mathrm{M}_{2}$ compared to $\mathrm{M}_{1}$ and $4.0 \%, 6.7 \%, 6.0 \%$ and $12.6 \%$, respectively for planting method $\mathrm{M}_{3}$ compared to $\mathrm{M}_{1}$ as an average for both growing seasons. These results agree with those obtained by Ahmad et al. (2010); Marey (2015); Moursi and El-Mansoury (2015); Zohry and Ouda (2019). They reported a reduction of root yield, sugar yield, sucrose percentage and juice purity under ridges planting method compared to raised-beds planting method. Sugar beet growth was better on raised-beds in most of parameters, the comparatively better response of bed over ridge planting may be due to the faster warms and dries out on raised-beds more quickly than soil at ground level (Starbuck 2005 and Ahmad et al. 2010). The reduction of TSS, sucrose percentage, root yield and sugar yield with planting method $\mathrm{M}_{1}$ may be due to the high values of DS and DI, which were recorded with $M_{1}$ as reported and harmony above with Harveson and Rush (2002) compared to $M_{2}$ and $\mathrm{M}_{3}$ as shown above in Table (4). Application of copper sulfate had a significant effect to increase abovementioned parameters, when increased copper sulfate concentration, TSS, sucrose percentage, root yield and sugar yield were increased.

The values of TSS, sucrose percentage, root yield and sugar yield for copper sulfate treatment of $\mathrm{Cu}_{2}$ were increased by $7.4 \%, 6.4 \%, 19.2 \%, 26.8 \%$, respectively compared to treatment $\mathrm{Cu}_{0}$ as mean of both growing seasons. These results may be attributed to the certain role of copper sulfate to reduce root rot disease, implying that improving root and sugar yield, as stated by Capinera and Dickens (2016) and Verma et al. (2011), they showed that the $\mathrm{Cu}$ application in the field prevented infection by plant pathogens. There are significant differences of sugar beet yield quantity and quality of the interaction between planting methods and copper sulfate concentrations. The highest values of TSS, sucrose percentage, root yield and sugar yield were found after $\mathrm{M}_{2} \mathrm{xCu}_{2}$ interaction, while the lowest values of these parameters were found after $\mathrm{M}_{1} \times \mathrm{Cu}_{0}$ interaction in the $1^{\text {st }}$ and $2^{\text {nd }}$ seasons. The interaction of $\mathrm{M}_{2}$ 
$\mathrm{x} \mathrm{Cu}_{2}$ was increased the values of TSS, sucrose percentage, root yield and sugar yield by $16.4 \%, 17.0 \%$, $31.6 \%$ and $53.7 \%$, respectively, compared to $\mathrm{M}_{1} \times \mathrm{Cu}_{0}$ interaction as mean of 2017/2018 and 2018/2019 seasons. The reduction of sucrose percentage under ridges planting methods may be attributed to the increase of soil moisture content in the root zone as affected by the presence of water on both sides of the ridge (Marey 2015). These results disclosed that a certain role of the interaction of planting methods and copper sulfate to enhance sugar beet yield and its quality.

Table 5: Effect planting methods and copper sulfate on total soluble solids, sucrose, root yield and sugar yield of sugar beet in 2017/18 and 2018/19 seasons.

\begin{tabular}{|c|c|c|c|c|c|c|c|c|c|c|}
\hline \multicolumn{3}{|c|}{ Treatments } & \multicolumn{2}{|c|}{$\begin{array}{l}\text { TSS } \\
(\%)\end{array}$} & \multicolumn{2}{|c|}{$\begin{array}{c}\text { Sucrose } \\
(\%)\end{array}$} & \multicolumn{2}{|c|}{$\begin{array}{l}\text { Root yield } \\
\left(\text { ton } \mathrm{ha}^{-1} \text { ) }\right.\end{array}$} & \multicolumn{2}{|c|}{$\begin{array}{c}\text { Sugar yield } \\
\left(\mathrm{kg} \mathrm{ha}^{-1}\right)\end{array}$} \\
\hline \multicolumn{3}{|c|}{ Seasons } & $\begin{array}{c}1^{\text {st }} \\
\text { season }\end{array}$ & $\begin{array}{c}2^{\text {nd }} \\
\text { season }\end{array}$ & $\begin{array}{c}1^{\text {st }} \\
\text { season }\end{array}$ & $\begin{array}{c}2^{\text {nd }} \\
\text { season }\end{array}$ & $\begin{array}{c}1^{\text {st }} \\
\text { season }\end{array}$ & $\begin{array}{c}2^{\text {nd }} \\
\text { season }\end{array}$ & $\begin{array}{c}1^{\text {st }} \\
\text { season }\end{array}$ & $\begin{array}{c}2^{\text {nd }} \\
\text { season }\end{array}$ \\
\hline \multirow{3}{*}{\multicolumn{2}{|c|}{ 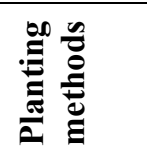 }} & $\mathbf{M}_{1}$ & $20.87 \mathrm{~b}$ & $19.04 \mathrm{a}$ & $16.52 \mathrm{~b}$ & $15.19 \mathrm{~b}$ & $35.97 \mathrm{c}$ & $38.60 \mathrm{c}$ & $5957 \mathrm{~b}$ & $5879 \mathrm{c}$ \\
\hline & & $\mathbf{M}_{2}$ & $23.14 \mathrm{a}$ & $19.29 \mathrm{a}$ & $18.49 \mathrm{a}$ & $15.53 \mathrm{a}$ & $40.48 \mathrm{a}$ & $43.38 \mathrm{a}$ & 7489 a & $6760 \mathrm{a}$ \\
\hline & & $\mathbf{M}_{3}$ & $23.09 \mathrm{a}$ & $18.42 \mathrm{~b}$ & $19.17 \mathrm{a}$ & $14.67 \mathrm{c}$ & $37.91 \mathrm{~b}$ & $41.16 \mathrm{~b}$ & $7284 \mathrm{a}$ & $6043 \mathrm{~b}$ \\
\hline \multirow{3}{*}{\multicolumn{2}{|c|}{ 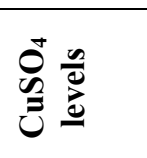 }} & $\mathrm{Cu}_{1}$ & $2.88 \mathrm{a}$ & $18.88 \mathrm{~b}$ & $18.21 \mathrm{a}$ & $15.21 \mathrm{~b}$ & $39.30 \mathrm{a}$ & $42.38 \mathrm{~b}$ & $7182 \mathrm{a}$ & $6453 \mathrm{~b}$ \\
\hline & & $\mathrm{Cu}_{2}$ & $23.13 \mathrm{a}$ & $19.69 \mathrm{a}$ & $18.42 \mathrm{a}$ & $15.68 \mathrm{a}$ & $40.89 \mathrm{a}$ & $43.84 \mathrm{a}$ & $7538 \mathrm{a}$ & $6873 \mathrm{a}$ \\
\hline & & $\mathrm{Cu}_{0}$ & $21.69 \mathrm{~b}$ & $18.18 \mathrm{c}$ & $17.55 \mathrm{~b}$ & $14.51 \mathrm{c}$ & $34.17 \mathrm{~b}$ & $36.91 \mathrm{c}$ & $6010 \mathrm{~b}$ & $5357 \mathrm{c}$ \\
\hline \multirow{8}{*}{ 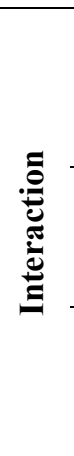 } & & $\mathbf{C u}_{1}$ & $21.53 \mathrm{c}$ & $18.81 \mathrm{~b}$ & $16.97 \mathrm{~d}$ & $15.04 \mathrm{c}$ & $34.97 \mathrm{~cd}$ & $39.27 \mathrm{e}$ & $5934 \mathrm{~d}$ & $5907 \mathrm{~d}$ \\
\hline & $\mathbf{M}_{1}$ & $\mathrm{Cu}_{2}$ & $21.33 \mathrm{c}$ & $20.33 \mathrm{a}$ & $16.81 \mathrm{~d}$ & $16.27 \mathrm{a}$ & $40.50 \mathrm{a}$ & $40.80 \mathrm{~d}$ & $6817 \mathrm{~b}$ & $6632 c$ \\
\hline & & $\mathbf{C u}_{0}$ & $19.73 \mathrm{~d}$ & $18.00 \mathrm{c}$ & $15.79 \mathrm{e}$ & $14.27 \mathrm{e}$ & $32.43 \mathrm{~d}$ & $35.73 \mathrm{~g}$ & $5119 \mathrm{e}$ & $5099 \mathrm{f}$ \\
\hline & & $\mathrm{Cu}_{1}$ & $22.77 \mathrm{~b}$ & $19.20 \mathrm{~b}$ & $18.21 \mathrm{c}$ & $15.63 \mathrm{~b}$ & $41.87 \mathrm{a}$ & $45.20 \mathrm{~b}$ & $7618 \mathrm{a}$ & $7066 \mathrm{~b}$ \\
\hline & $\mathbf{M}_{2}$ & $\begin{array}{l}\mathrm{Cu}_{2} \\
\mathrm{Cu}_{0}\end{array}$ & $\begin{array}{l}.80 \mathrm{a} \\
.87 \mathrm{~b}\end{array}$ & $\begin{array}{c}20.13 \mathrm{a} \\
18.53 \mathrm{bc}\end{array}$ & $\begin{array}{r}19.04 \mathrm{ab} \\
18.23 \mathrm{c}\end{array}$ & $\begin{array}{c}16.14 \mathrm{a} \\
14.83 \mathrm{~cd}\end{array}$ & $\begin{array}{c}42.44 \mathrm{a} \\
37.13 \mathrm{bc}\end{array}$ & $\begin{array}{l}47.27 \mathrm{a} \\
37.67 \mathrm{f}\end{array}$ & $\begin{array}{l}8082 \mathrm{a} \\
6767 \mathrm{bc}\end{array}$ & $\begin{array}{l}7627 \mathrm{a} \\
5588 \mathrm{e}\end{array}$ \\
\hline & & $\mathrm{Cu}_{1}$ & $24.33 \mathrm{a}$ & $18.67 \mathrm{bc}$ & $19.47 \mathrm{a}$ & $14.96 \mathrm{c}$ & $41.07 \mathrm{a}$ & $42.67 \mathrm{c}$ & $7994 \mathrm{a}$ & $6385 \mathrm{c}$ \\
\hline & $\mathbf{M}_{3}$ & $\mathrm{Cu}_{2}$ & $24.27 \mathrm{a}$ & $18.60 \mathrm{bc}$ & $19.41 \mathrm{a}$ & $14.63 \mathrm{cde}$ & $39.73 \mathrm{ab}$ & $43.47 \mathrm{c}$ & $7715 \mathrm{a}$ & $6359 \mathrm{c}$ \\
\hline & & $\mathbf{C u}_{0}$ & $22.47 \mathrm{~b}$ & $18.00 \mathrm{c}$ & $18.64 \mathrm{bc}$ & $14.42 \mathrm{de}$ & $32.93 \mathrm{~d}$ & $37.33 \mathrm{f}$ & $6144 \mathrm{~cd}$ & $5385 \mathrm{e}$ \\
\hline
\end{tabular}

Means followed by the same partition lower cases letter within a character are not significantly different, $\mathrm{P}=0.05 \%$.

\section{Productivity of irrigation water and water productivity:}

Productivity of irrigation water of root yield $\left(\mathrm{PIW}_{\mathrm{R}}\right)$ and water productivity of root yield $\left(\mathrm{WP}_{\mathrm{R}}\right)$ are presented in Table (6). There are significant differences between all studied planting methods, the lowest values of PIW ${ }_{R}$ and $W_{R} P_{R}$ were $5.87 \mathrm{~kg} \mathrm{~m}^{-3}$ and $8.44 \mathrm{~kg} \mathrm{~m}^{-3}$, respectively for $\mathrm{M}_{1}$ compared to $\mathrm{M}_{2}$ and $\mathrm{M}_{3}$ as an average of the two growing seasons. Planting methods of $\mathrm{M}_{2}$ and $\mathrm{M}_{3}$ increased PIWR by $38.3 \%$ and $39.7 \%$, while it increased $\mathrm{WP}_{\mathrm{R}}$ by $22.2 \%$ and $25.0 \%$, respectively compared to $\mathrm{M}_{1}$ as a mean for both seasons. The reduction of $\mathrm{PIW}_{\mathrm{R}}$ and $\mathrm{WP}_{\mathrm{R}}$ under ridges planting method compared to raisedbeds may be due to the increment of applied water and water consumptive use respectively (Moursi and El-Mansoury 2015), this parallel to decrease of root rot disease severity and incidence with $\mathrm{M}_{2}$. Also, may be attributed to the reduction of applied water and increasing the root yield (Marey 2015). The values of $P I W_{R}$ and $W_{R}$ were increased when copper sulfate concentration increased, $\mathrm{PIW}_{R}$ was increased by $10.6 \%$ after $\mathrm{Cu}_{1}$ and $\mathrm{Cu}_{2}$ compared to $\mathrm{Cu}_{0}$, however $\mathrm{WP}_{\mathrm{R}}$ was increased by $12.7 \%$ and $14.5 \%$ for $\mathrm{Cu}_{1}$ and $\mathrm{Cu}_{2}$, respectively compared to $\mathrm{Cu}_{0}$ as a mean for both seasons. This as a result of increasing root yield, which were increased when increasing copper sulfate concentration $\left(\mathrm{Cu}_{2}\right)$, that associated with decreasing of root rot disease. The interaction between planting methods and copper sulfate concentrations had a significant effect on $\mathrm{PIW}_{\mathrm{R}}$ and $\mathrm{WP}_{\mathrm{R}}$. The interaction of $\mathrm{M}_{2} \times \mathrm{Cu}_{2}$ caused an increment of $\mathrm{PIW}_{\mathrm{R}}$ and $\mathrm{WP}_{\mathrm{R}}$ by $50.4 \%$ and $37.4 \%$ respectively compared to $\mathrm{M}_{1} \times \mathrm{Cu}_{0}$ as a mean for the two seasons as shown in Table (6). These results may be due to the good benefits of raised beds on sugar beet yield, TSS, sugar and sugar yield resulting of decrease of disease severity and incidence. As well as, improving water distribution and efficiency (Ahmad et al. 2009), and improves soil quality, which led to enhance root growth (Limon-Ortega et al. 2002). In addition, increase radiation use efficiency of sugar beet, which led to increase nutrients use efficiency, final root yield and water use efficiency (Ahmad et al. 2010). 
Table 6: Productivity of irrigation water and water productivity of root yield as affected by planting methods and copper sulfate application for both growing seasons.

\begin{tabular}{|c|c|c|c|c|c|c|c|c|}
\hline \multicolumn{9}{|c|}{ PIW $_{R}$} \\
\hline \multirow[t]{2}{*}{ Treatments } & \multicolumn{4}{|c|}{ 2017/2018 Season } & \multicolumn{4}{|c|}{ 2018/2019 Season } \\
\hline & Cu 1 & $\mathrm{Cu} 2$ & Cu 0 & Mean & Cu 1 & $\mathrm{Cu} 2$ & $\mathrm{Cu} 0$ & Mean \\
\hline $\mathbf{M}_{1}$ & $5.50 \mathrm{e}$ & $6.07 \mathrm{~d}$ & $5.41 \mathrm{e}$ & $5.66 \mathrm{~b}$ & $6.18 \mathrm{~d}$ & $6.11 \mathrm{~d}$ & $5.96 \mathrm{~d}$ & $6.08 \mathrm{c}$ \\
\hline $\mathbf{M}_{2}$ & $8.04 \mathrm{ab}$ & $8.25 \mathrm{ab}$ & $7.39 \mathrm{c}$ & $7.89 \mathrm{a}$ & $8.68 \mathrm{a}$ & $8.85 \mathrm{a}$ & $7.49 \mathrm{c}$ & $8.34 \mathrm{~b}$ \\
\hline $\mathbf{M}_{3}$ & $8.54 \mathrm{a}$ & $7.93 \mathrm{~b}$ & $7.12 \mathrm{c}$ & $7.86 \mathrm{a}$ & $8.87 \mathrm{a}$ & $8.67 \mathrm{a}$ & $8.07 \mathrm{~b}$ & $8.54 \mathrm{a}$ \\
\hline Mean & $7.36 \mathrm{a}$ & $7.42 \mathrm{a}$ & $6.64 \mathrm{~b}$ & & $7.91 \mathrm{a}$ & $7.88 \mathrm{a}$ & $7.17 \mathrm{~b}$ & \\
\hline \multicolumn{9}{|c|}{$\mathbf{W P}_{\mathbf{R}}$} \\
\hline & Cu 1 & Cu 2 & Cu 0 & Mean & Cu 1 & Cu 2 & Cu 0 & Mean \\
\hline $\mathbf{M}_{1}$ & $7.94 \mathrm{c}$ & $8.96 \mathrm{~b}$ & $7.51 \mathrm{c}$ & $8.14 \mathrm{~b}$ & $8.91 \mathrm{~d}$ & $9.03 \mathrm{~d}$ & $8.28 \mathrm{e}$ & $8.74 \mathrm{c}$ \\
\hline $\mathbf{M}_{2}$ & $10.29 \mathrm{a}$ & $10.26 \mathrm{a}$ & $9.30 \mathrm{~b}$ & $9.95 \mathrm{a}$ & $11.11 \mathrm{a}$ & $11.43 \mathrm{a}$ & $9.44 \mathrm{c}$ & $10.66 \mathrm{~b}$ \\
\hline $\mathbf{M}_{3}$ & $10.83 \mathrm{a}$ & $10.42 \mathrm{a}$ & $8.98 \mathrm{~b}$ & $10.08 \mathrm{a}$ & $11.43 \mathrm{a}$ & $11.40 \mathrm{a}$ & $10.18 \mathrm{~b}$ & $11.01 \mathrm{a}$ \\
\hline Mean & $9.69 \mathrm{a}$ & $9.88 \mathrm{a}$ & $8.60 \mathrm{~b}$ & & $10.49 \mathrm{a}$ & $10.62 \mathrm{a}$ & $9.30 \mathrm{~b}$ & \\
\hline
\end{tabular}

Means followed by the same lower cases letter within a character are not significantly different, $\mathrm{P}=0.05 \%$.

Data in Fig. (1) illustrated productivity of irrigation water for sugar yield $\left(\mathrm{PIW}_{\mathrm{s}}\right)$ and water productivity of sugar yield $\left(\mathrm{WP}_{\mathrm{s}}\right)$.
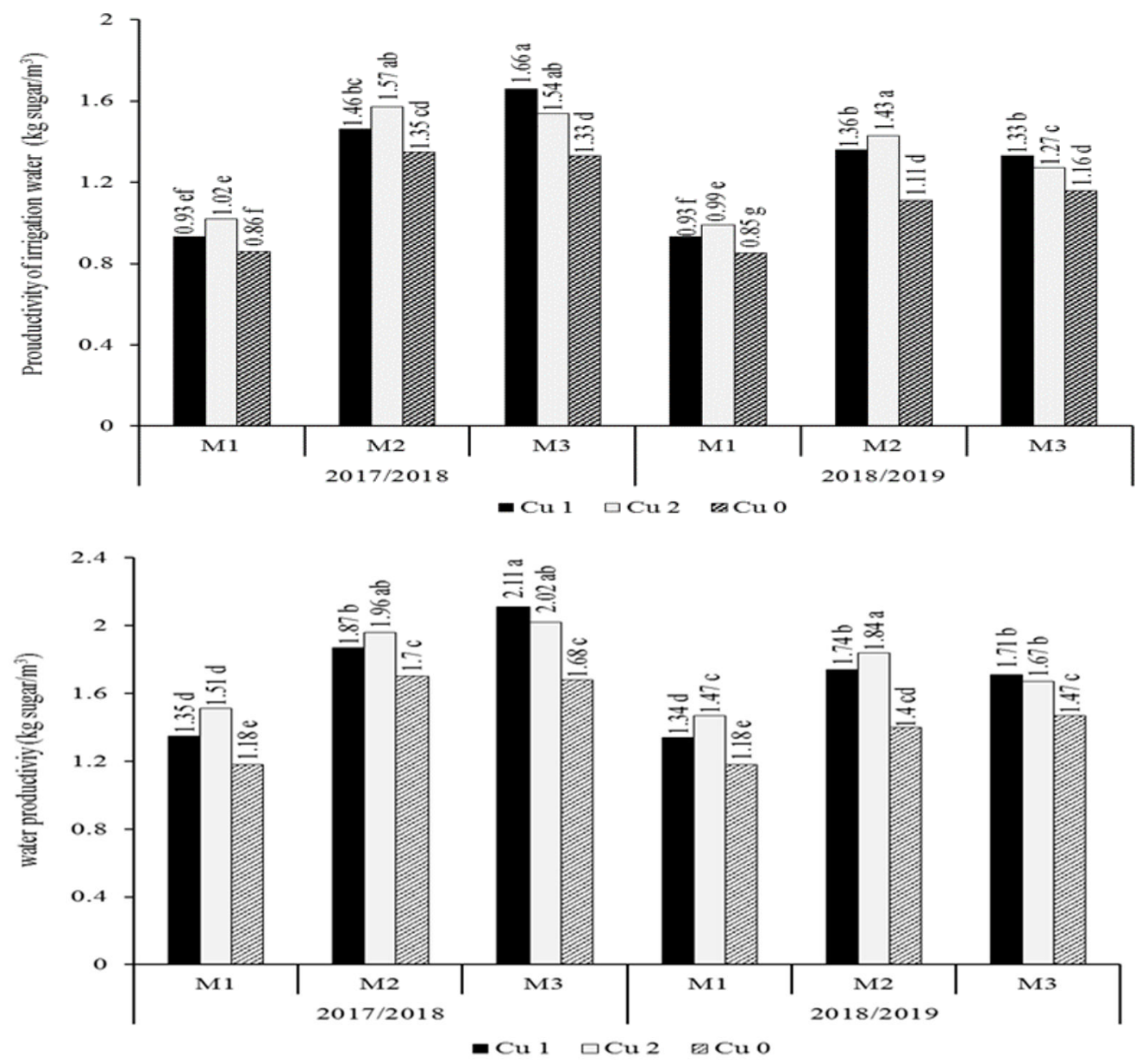

Fig.1: Productivity of irrigation water and water productivity of sugar yield as affected by planting methods and copper sulfate application on both growing seasons.

A significant difference of $\mathrm{PIW}_{\mathrm{s}}$ and $\mathrm{WP}_{\mathrm{s}}$ values were found between different studied planting methods, the values of $\mathrm{PIW}_{\mathrm{s}}$ were $0.93,1.38$ and $1.38 \mathrm{~kg}$ sugar $\mathrm{m}^{-3}$ and $\mathrm{WP}_{\mathrm{s}}$ values were $1.34,1.75$ and $1.78 \mathrm{~kg}$ sugar $\mathrm{m}^{-3}$ for $\mathrm{M}_{1}, \mathrm{M}_{2}$ and $\mathrm{M}_{3}$ respectively as mean of both seasons. There are significant differences of $\mathrm{PIW}_{\mathrm{s}}$ and $\mathrm{WP}_{\mathrm{s}}$ were recorded between different copper sulfate levels and the interaction between planting methods and copper sulfate concentrations, it was taken the same trend of $\mathrm{PIW}_{\mathrm{R}}$ and $\mathrm{WP}_{\mathrm{R}}$. 
Copper sulfate treatment $\mathrm{Cu}_{1}$ and $\mathrm{Cu}_{2}$ were increased $\mathrm{PIW}_{\mathrm{s}}$ by $15.3 \%$ and $18.0 \%$, respectively, however they increased $\mathrm{WP}_{\mathrm{s}}$ by $18.2 \%$ and $22.4 \%$ respectively compared to $\mathrm{Cu}_{0}$ as an average of both seasons.

The interaction of $\mathrm{M}_{2} \times \mathrm{Cu}_{2}$ was increased $\mathrm{PIW}_{\mathrm{s}}$ and $\mathrm{WP}_{\mathrm{s}}$ by $74.4 \%$ and $61.0 \%$ respectively compared to $\mathrm{M}_{1} \times \mathrm{Cu}_{0}$ as a mean for the two seasons as shown in the same figure. These results are in a great harmony with those obtained by Marey (2015) who found the lowest value of the water use efficiency was achieved under ridges compared to raised-beds planting method.

\section{Effect Copper sulfate on root rots fungi in vitro:}

Data in Table (7) showed that, three concentrations of copper sulfate were tested against growth and sporulation and /or sclerotia formation of three main root rot pathogens of F.oxysporum, R.solani and Sc.rolfsii of sugar beet crop and results indicated that, increasing of copper sulfate testing concentration led to increasing inhibition of mycelial growth, sporulation and / or sclerotia production with the tested fungi. F. oxysporum fungus was the most effective one in the retarding which recorded the highest inhibition of growth and sporulation ranged from $76.86-96.69 \%$ followed by R.solani, ie. 52.01- 83.25\%, while the lowest one was Sc.rolfsii , ie. 7.44-67.52\%. At all, $7.5 \mathrm{~g} / \mathrm{L}$ copper sulfate of PDA medium was the most inhibitory concentration of growth of F.oxysporum compared with control , ie. 1.16 compared $8.51 \mathrm{~cm}$, sporulation $0.16 \times 10^{6}$ compared $5.16 \times 10^{6}$; followed by R.solani ie. 4.06 compared to $9.00 \mathrm{~cm}$ and 1.01 compared to 6.03 sclerotia and Sc.rolfsii showed 4.12 compared $9.00 \mathrm{~cm}$ and 54.66 compared 168.33 sclerotia formation, respectivly . Farahat et al. (2011) and Elmoghazy et al. (2011) supported the present results and found that, sulfate of $\mathrm{Cu}$ was significantly reduced the growth and effective in retarding of the fungus of $C$. beticola fungus in vitro. Saharan et al. (2015) reported that, $\mathrm{CuSO}_{4}$ was inhibited mycelial growth and spores germination of A.solani and F. oxysporum (casuals of early blight and wilt of tomato). Copper based antimicrobial with high toxicity to plant pathogens (Lamichhane et al., 2018). Moreover, Farahat and Salama (2019) added that $\mathrm{CuSO}_{4}$ was the most effected sulfates one in reducing and retarding of Erysiphe betae fungus spores germination in vitro.

Table 7: Effect of copper sulfate on growth of $F$. oxysporum, $R$. solani, Sc. rolfsii and sporulation or sclerotia production.

\begin{tabular}{ccccccc}
\hline Fungi & \multicolumn{2}{c}{ F.oxysporum } & \multicolumn{2}{c}{ R.solani } & \multicolumn{2}{c}{ Sc.rolfsii } \\
\hline $\begin{array}{c}\text { Concentration } \\
\text { g/L PDA }\end{array}$ & $\begin{array}{c}\text { Growth } \\
\text { (m }\end{array}$ & $\begin{array}{c}\text { Inhibition } \\
\text { \% }\end{array}$ & $\begin{array}{c}\text { Growth } \\
\text { (m }\end{array}$ & $\begin{array}{c}\text { Inhibition } \\
\text { \% }\end{array}$ & $\begin{array}{c}\text { Growth } \\
\text { (m }\end{array}$ & $\begin{array}{c}\text { Inhibition } \\
\text { \% }\end{array}$ \\
\hline $\mathbf{2 . 5}$ & $1.97 \mathrm{~b}$ & $76.86 \mathrm{c}$ & $4.32 \mathrm{~b}$ & $52.01 \mathrm{c}$ & $8.33 \mathrm{~b}$ & $7.44 \mathrm{c}$ \\
$\mathbf{5 . 0}$ & $1.36 \mathrm{c}$ & $84.41 \mathrm{~b}$ & $4.24 \mathrm{~b}$ & $52.85 \mathrm{~b}$ & $5.09 \mathrm{c}$ & $43.44 \mathrm{~b}$ \\
$\mathbf{7 . 5}$ & $1.16 \mathrm{~d}$ & $86.37 \mathrm{a}$ & $4.06 \mathrm{~b}$ & $54.88 \mathrm{a}$ & $4.12 \mathrm{~d}$ & $54.22 \mathrm{a}$ \\
Control & $8.51 \mathrm{a}$ & - & $9.00 \mathrm{a}$ & - & $9.00 \mathrm{a}$ & - \\
\hline & Spores & Inhibition & Sclerotia & Inhibition & Sclerotia & Inhibition \\
& $\mathbf{x 1 0 ^ { 6 }}$ & $\mathbf{\%}$ & No. & \% & No. & \% \\
\hline $\mathbf{2 . 5}$ & $1.16 \mathrm{~b}$ & $77.15 \mathrm{c}$ & $1.04 \mathrm{~b}$ & $82.75 \mathrm{c}$ & $126.66 \mathrm{~b}$ & $24.75 \mathrm{c}$ \\
$\mathbf{5 . 0}$ & $0.33 \mathrm{c}$ & $93.60 \mathrm{~b}$ & $1.02 \mathrm{~b}$ & $83.08 \mathrm{~b}$ & $85.01 \mathrm{c}$ & $49.65 \mathrm{~b}$ \\
$\mathbf{7 . 5}$ & $0.16 \mathrm{~d}$ & $96.89 \mathrm{a}$ & $1.01 \mathrm{~b}$ & $83.25 \mathrm{a}$ & $54.66 \mathrm{~cd}$ & $67.52 \mathrm{a}$ \\
Control & $5.16 \mathrm{a}$ & - & $6.03 \mathrm{a}$ & - & $168.33 \mathrm{a}$ & - \\
\hline
\end{tabular}

Means followed by the same lower cases letter within a character are not significantly different, $\mathrm{P}=0.05 \%$.

\section{Economic feasibility:}

The detailed economic analysis as an average of the both studied seasons are presented in Table (8). It included the total variable and fixed production costs as land preparation, sowing, irrigation, fertilization, insects, weeds controls and the rent, average gross income, profit margin, return of pounds and benefit / costs ratio. The total production costs ranged from 14875 to $15529 \mathrm{LE}$. ha ${ }^{-1}$. The highest average gross income was recorded for the interaction of $\mathrm{M}_{2} \times \mathrm{Cu}_{2}$ and $\mathrm{M}_{2} \times \mathrm{Cu}_{1}$, to be 24923 and 24352 LE. ha ${ }^{-1}$, respectively, while the lowest value of gross income was obtained of $\mathrm{M}_{1} \times \mathrm{Cu}_{0}$, it recorded 17992 LE. ha ${ }^{-1}$, other treatments ranged from 19841 to $23951 \mathrm{LE}$. ha ${ }^{-1}$. The interaction of $\mathrm{M}_{2} \times \mathrm{Cu}_{2}$ recorded the highest values of other economic parameters, viz. net return, profit margin, return of pounds and benefit / cost ratio compared to all other studied interactions, it recorded 9489, 0.381, 0.651 and 
1.615, respectively, followed by $\mathrm{M}_{2} \times \mathrm{Cu}_{1}, \mathrm{M}_{3} \times \mathrm{Cu}_{1}$ and $\mathrm{M}_{3} \times \mathrm{Cu}_{2}$ treatments. This interaction $\mathrm{M}_{2} \times \mathrm{Cu}_{2}$ increased gross income, net return, profit margin, return of pounds and benefit / cost ratio by $38 \%$, $216 \%, 128 \%, 206 \%$ and $35 \%$, respectively ,compared to $\mathrm{M}_{1} \times \mathrm{Cu}_{0}$. These increment may be due to the superior of $\mathrm{M}_{2} \times \mathrm{Cu}_{2}$ interaction on root yield and sugar yield, thus the return and profit were increased from available resources. These results were in harmony with previous reported by Ahmad et al. (2010).

Table 8: Effect of planting methods and copper sulfate treatments on economic parameters of sugar beet crop as mean of 2017/2018 and 2018/2019 seasons.

\begin{tabular}{|c|c|c|c|c|c|c|c|}
\hline \multicolumn{2}{|c|}{ Treatments } & $\begin{array}{l}\text { Production } \\
\text { costs } \\
\left(\text { LE. ha }{ }^{-1}\right)\end{array}$ & $\begin{array}{c}\text { Gross } \\
\text { income } \\
\left(\text { LE. ha }{ }^{-1}\right)\end{array}$ & $\begin{array}{l}\text { Net return } \\
\left(\text { LE. } \text { ha }^{-1}\right)\end{array}$ & $\begin{array}{c}\text { Profit } \\
\text { margin } \\
\left(\text { LE. ha }{ }^{-1}\right)\end{array}$ & $\begin{array}{c}\text { Return } \\
\text { of pound }\end{array}$ & $\begin{array}{l}\mathrm{B} / \mathrm{C} \\
\text { ratio }\end{array}$ \\
\hline \multirow{3}{*}{$\mathbf{M}_{1}$} & $\mathbf{C} \mathbf{u}_{1}$ & 15351 & 19936 & 4585 & 0.230 & 0.299 & 1.299 \\
\hline & $\mathrm{Cu}_{2}$ & 15529 & 21768 & 6239 & 0.287 & 0.402 & 1.402 \\
\hline & $\mathbf{C u}_{0}$ & 14994 & 17992 & 2998 & 0.167 & 0.201 & 1.199 \\
\hline \multirow{3}{*}{$\mathbf{M}_{2}$} & $\mathbf{C} \mathbf{u}_{1}$ & 15255 & 24352 & 9097 & 0.374 & 0.596 & 1.596 \\
\hline & $\mathrm{Cu}_{2}$ & 15434 & 24923 & 9489 & 0.381 & 0.615 & 1.615 \\
\hline & $\mathbf{C u}_{0}$ & 14898 & 21162 & 6264 & 0.296 & 0.420 & 1.420 \\
\hline \multirow{3}{*}{$\mathbf{M}_{3}$} & $\mathbf{C} \mathbf{u}_{1}$ & 15232 & 23951 & 8628 & 0.360 & 0.566 & 1.572 \\
\hline & $\mathrm{Cu}_{2}$ & 15410 & 23683 & 8273 & 0.349 & 0.569 & 1.537 \\
\hline & $\mathbf{C u}_{0}$ & 14875 & 19841 & 4966 & 0.250 & 0.537 & 1.338 \\
\hline
\end{tabular}

\section{Conclusion}

In such socio-ecological conditions that, most farmers have small land holdings and they have poor financial resources, the appropriate management and good agronomic practices as raised-beds planting method can make the farmer to reap maximum profit from available recourses. From the current study, it could be concluded the interaction of raised bed planting method $1.20 \mathrm{~m}$ apart and copper sulfate at concentration of $10.71 \mathrm{~kg} \mathrm{ha}^{-1}\left(\mathrm{M}_{2} \times \mathrm{Cu}_{2}\right)$, because it achieved the highest TSS, sucrose $\%$, root yield, sugar yield, gross income, net return, profit margin, return of pounds and benefit / costs ratio and reduced root rot disease severity and index, applied water and water consumptive use, moreover it enhanced $\mathrm{PIW}_{\mathrm{R}}, \mathrm{WP}_{\mathrm{R}}, \mathrm{PIW}_{\mathrm{S}}$ and $\mathrm{WP}_{\mathrm{S}}$. Consequently, $\mathrm{M}_{2} \mathrm{Cu}_{2}$ interaction had the potential to maximize the use of soil and water resources and farmer profit. Given these observation, it was hypothesized that, it may be possible to use it in an alternate approach.

\section{Acknowledgement:}

We would like to express thanks and gratitude to all staff member in Plant Pathology and Water requirements and field irrigation Depts. for kind help, faithful effort and advising us during this research.

\section{References}

Ali, M.H., M.R. Hoque, A.A. Hassan and A. Khair, 2007. Effect of deficit irrigation on yield water productivity and economic returns of wheat. Agricultural Water Management, 92: 151-161.

Ahmad, I.M., B. Qubal, G. Ahmad and N.H. Shah, 2009. Maize yield, plant tissue and residual soil N as affected by nitrogen management and tillage system. J. Agric. Biol. Sci., 1(1):19-29.

Ahmad, Z., P. Shah, K.M. Kakar, H. El-Sharkawi, P.B.S. Gama, E.A. Khan, T. Honna and S. Yamamoto, 2010. Sugar beet (Beta vulgaris L.) response to different planting methods and row geometries II: Effect on plant growth and quality. J. Food Agric. Environ., 8 (2):785-791.

Aly, M.H. and M.Y. Hussein, 2009. Vesicular - Arbuscular Mycorrhiza and Trichoderma viridi as deterrents against soil-borne root rot disease of sugar beet. Plant Disease Research Institute, Agriculture Research Center, Giza, Egypt, 11: 387 - 391.

AOAC, Association of Official Analytical Chemists, 2005. Official Methods of Analysis of the Association of Official Analytical Chemists. $18^{\text {th }} \mathrm{Ed}$. Washington, DC, USA.

Bartholomaus, A., S. Mittler, B. Marlander, and M. Varrelmann, 2017. Control of Rhizoctonia solani in sugar beet and effect of fungicide application and plant cultivar on inoculum potential in the soil. Plant Disease, 101:941-947. 
Black, C.A., 1965. Methods of Soil Analysis: 2 Parts. American Society of Agronomy.

Capinera, J.L. and K. Dickens, 2016. Some effects of copper based fungicides on plant feeding terrestrial molluscs: a role for repellents in molluscs management. Crop Prot., 83:76-82.

Duncan, D.B., 1955. Multiple range and multiple F-tests. Biometrics, 11: 1-42.

Early, A.C., 1975. Irrigation Scheduling for Wheat in the Punjab. CENTO Scientific Program on the Optimum Use of Water in Agriculture: Report No. 17. CENTO, Lyllpur, Pakistan, 115-127 pp.

Eliwa, M.A., M.M. El-Skeikh Aly, H.M. Abd-Alla, and A.A. Galal, 2018. Efficacy of certain fungicide alternatives for controlling sugar beet powdery mildew .J. of Phytopath. and Pest Manag. 5:1:76-87.

El-moghazy, S.M., G.A. El-Kot, and A.M. Hamza, 2011. Control of sugar beet leaf spot disease caused by the fungus Cercospora beticola (Sacc).J. Plant Proc. and Path. Mansoura Univ., 2:11:10371047.

El-Shamy, Moshira, A., Mona A.M. El-Mansoury and Marwa Kh.A. Mohamed, 2019. Effect of irrigation and furrow width on sugar beet and faba bean productivity under intercropping patterns and some water relations in clay soil. J. of Soil Sci. and Agric. Eng., Mansoura Univ., 10(10): $567-577$.

FAO, 2018. Food and Agriculture organisation statistical database. Avilable at faostat. External. FAO. Org./faostat.

Farahat, G.A., 2019. Potential impacts of copper sulfate and sodium silicate salts of maize late wilt disease in field disease nursery and synthase of anti-defense compounds . Env. Biodiv. Soil Security, $3: 269$ - 282 .

Farahat, G.A. and N.H.H. Salama, 2019. Potential impacts of climatic conditions and some sulfates on sugar beet powdery mildew disease incited by Erysiphe betae fungus in the field. Egypt. J. Plant Pro. Res., 7:2: 52- 73.

Farahat, G.A., N.H.H. Salama, and A.A. Shahin, 2011. Effect of cercosporin toxin on sugar beet plants and control of cercospora leaf spot disease by micronutrients \& phosphate and plant hormones in the field. J. Agric. Res. Kafer El-Seikh Univ., 37 (2): 223-238.

Fidah, A., 1995. La pourriture de la betterave à sucre due à Sclerotium rolfsii dans les Doukalla: Epidemiologie et essais de lutte. Thèse de troisième cycle, Faculté des Sciences Semlalia, Marrakesch, Morocco.

Fleming, C.A. and J.T. Trevors, 1989. Copper toxicity and biochemistry in the environment: a review .Water Air Soil Polu., 44:143-158.

Graham, R.D. and M.J. Webb, 1991. Micronutrients and disease resistance and tolerance in plants .In Welch, editor Welch RM, editor . Micronutrients in Agriculture Madison, Wise: Soil Sci. Soc. of America: 329-370.

Harveson, R.M. and C.M. Rush, 1994. Evaluation of fumigation and rhizomaia -tolerant cultivars for control of a disease complex of sugar beet. Plant Disease, 78:1197-1202.

Harveson, R.M. and C.M. Rush, 2002.The influence of irrigation and cultivar blends on the severity of multiple root diseases in sugar beets .Plant Disease, 86:901-908.

Heady, E.O. and J.L. Dillon, 1961. Agricultural production function library of congress catalog card number: 60-1128, Lowa State University Press.

Huber, D.M. and N.S. Withelm, 1998. The role of manganese in resistance to plant disease. In Graham RD, Hannam RJ, Uren NC, editors ; Graham RD, Hannam RJ, Uren NC, editors .Manganese in soil and plants. Dordrecht, The Netherlands: Kluwer Academic Publishers : 155-175.

Israelsen, O.W. and V.E. Hansen, 1962. Irrigation principles and practices $3^{\text {rd }}$ Ed. John Willey and Sons. Inc., New York.

Khambalkar, V.P., S.M. Nage, C.M. Rathod, A.V. Gajakos, and S. Dahatonde, 2010. Mechanical sowing of safflower on broad bed furrow. Australian Journal of Agricultural Engineering, 1(5): 184-187.

Klute, A., 1986. Methods of soil analysis, part 1: physical and Miner-alogical methods $\left(2^{\text {nd }}\right)$ Ed American Soci. of Agronomy, Madison, Wisconsin, USA.

Lamichhane, J.R, E. Osdaghi, F. Behlau, J. Kohl, J.B. Jones, and J.N. Aubertot, 2018. Thirteen decades of antimicrobial copper compounds applied in agriculture. A review. Agron. Sustain. Dev., $38: 28: 18$. 
Limon-Ortega, A., K.D. Sayre, R.A. Drijber and C.A. Francis, 2002. Soil attributes in a furrow-irrigated bed planting system in northwest Mexico. Soil Till. Res., 63:123-132.

Long, S., Y. Li, C. Shi, E. Li, Y. Zhang and M. Lei , 2003. Relations between sucrose and resistance of corn to stalk rot . J. of Northwest Sci. Tech. Univ. of Agric. and For., 31:4.

Majumdar, D.K., 2002. Irrigation Water Management: Principles and Practice. $2^{\text {nd }}$ Ed. Prentice Hall of India, New Delhi 110001, 487.

Mandeel, Q. and R. Baker, 1991. Mechanisms involved in biological control of fusarium wilt of cucumber with strains of nonpathogenic Fusarium oxysporum. Phytopathology, 81(4):462469.

Mahmoud, M.A., Azza, A. El-Hendawy and M.Y. Awad, 2016. Water productivity of some cotton varieties and yield under different irrigation methods. Assiut J. Agric. Sci., 47 (6-1): 203-216.

Marey, S. A., 2015. Affecting each of ridger furrow opener parameters and planting methods on water use efficiency and sugar beet yield. Bulgarian Journal of Agri. Sci., 21(6): 1304-1311.

McGinnis , R.A., 1982. Beet Sugar Technology. $3{ }^{\text {rd }}$ Ed. Beet Sugar Development Foundation. Fort Collins, $855 \mathrm{p}$.

Moursi, E.A. and Mona, A.M. El-Mansoury, 2015. Effect of cultivation method and different irrigation levels on water relations for sugar beet crop in north Nile delta region. J. Soil Sci. and Agric. Eng. Mansoura Univ., 6 (8): 983-999.

Page, A.L. (Ed.), 1982. Methods of Soil Analysis. Part 1: Physical properties and part 2: Chemical and microbiological properties. ( $3^{\text {nd }}$ Ed.) Amer. Soc. Agron., In Soil Sci. Soc. Amer. Inc., Madison, Wisconsin, USA.

Novica, V., 1979. Irrigation of Agriculture Crops. Faculty of Agriculture Press, Novi Sad, Yugoslavia

Precigout, P.A., D. Claessen and C. Robert, 2017.Crop fertilization impacts epidemics and optimal latent period of biotrophic fungal pathogens .Phytopathologhy, 107:10:1256-1267.

Saharan, V., G. Sharama, M. Yadav, M.K. Choudhary, S.S. Sharma, A. Pal, R. Ralya, and P. Biswas, 2015. Synthesis and in vitro antifungal efficacy of $\mathrm{Cu}$-chitosan nanoparticles against pathogenic fungi of tomato. Int. J. of Boi. Macromolecules, 75:346-353.

Scott, R.K. and K.W. Jaggard, 1993. Crop physiology and agronomy. In Cooke, D. A. and Scott, R. K. (eds). The Sugar Beet Crop: Science into Practice. Chapman and Hall, London, 179-233.

Snedecor, G.W. and W.G. Cochran, 1971. Statistical Methods. $6^{\text {th }}$ Ed. Iowa State Univ. Press Amer, USA.

Starbuck, C.J., 2005. Raised bed gardening. MU Extension, University of Missouri. Columbia, MO 65211/G 6985. (Cited on $14^{\text {th }}$ November 2005 available at www.muextension.missouri.edu).

Verma, J.P., V. Singh, and J. Yadav, 2011. Effect of copper sulphate on seed germination, plant growth and peroxidase activity of mung bean. Int. J. Bot. 7:200-204.

Zhang, Q.T., O.A.B. Ahmed, M. Inoue, M.C. Saxena, K. Inosako, and K. Kondo, 2009. Effects of mulching on evapotranspiration, yield and water use efficiency of Swiss chard (Beta vulgaris L. var. Flavescens) irrigated with diluted seawater. Journal of Food and Agriculture Environment, 7(3-4): 650-654.

Zohry, A.A. and S.A. Ouda, 2019. Intercropping systems for sugar beet to improve its land and water productivity. J. Soils and Crops, 29(2): 218-226. 